\title{
Correction: Stratification of knee osteoarthritis: two major patient subgroups identified by genome-wide expression analysis of articular cartilage
}

Soul J, Dunn SL, Anand S, et al. Stratification of knee osteoarthritis: two major patient subgroups identified by genome-wide expression analysis of articular cartilage. Ann of Rheum Dis 2018;77:423-30. doi:10.1136/annrheumdis-2017-212603.

References 1 and 2 have been updated to:

1 Fernandez-Moreno M, Rego I, Carreira-Garcia V, et al. Genetics in Osteoarthritis. Curr Genomics 2008;9:542-7.

2 Panoutsopoulou K, Southam L, Elliott KS, et al. Insights into the genetic architecture of osteoarthritis from stage 1 of the arcOGEN study. Ann Rheum Dis 2011;70:864-7.

\section{(6) \\ OPEN ACCESS}

Open Access TThis is an Open Access article distributed in accordance with the terms of the Creative Commons Attribution (CC BY 4.0) license, which permits others to distribute, remix, adapt and build upon this work, for commercial use, provided the original work is properly cited. See: http://creativecommons.org/licenses/by/4.0/

(c) Article author(s) (or their employer(s) unless otherwise stated in the text of the article) 2018. All rights reserved. No commercial use is permitted unless otherwise expressly granted.

Ann Rheum Dis 2018;77:960. doi:10.1136/annrheumdis-2017-212603corr1

D) Check for updates 